Article

\title{
Environmental Sustainability of Creative Economy: Evidence from a Lithuanian Case Study
}

\author{
Tomas Kačerauskas $^{1}\left(\mathbb{D}\right.$, Dalia Streimikiene ${ }^{2, *(\mathbb{D})}$ and Rasa Bartkute ${ }^{3}$ \\ 1 Department of Philosophy and Cultural Studies, Faculty of Creative Industries, \\ Vilnius Gediminas Technical University, Traku 1, LT-01132 Vilnius, Lithuania; tomas.kacerauskas@vgtu.lt \\ 2 Institute of Sport Science and Innovations, Lithuanian Sports University, Sporto Str. 6, \\ LT-44221 Kaunas, Lithuania \\ 3 Kaunas Faculty, Vilnius University, Muitines 8, LT-44280 Kaunas, Lithuania; rasa.bartkute@knf.vu.lt \\ * Correspondence: dalia.streimikiene@knf.vu.lt
}

Citation: Kačerauskas, T.;

Streimikiene, D.; Bartkute, R. Environmental Sustainability of Creative Economy: Evidence from a Lithuanian Case Study. Sustainability 2021, 13, 9730. https://doi.org/ $10.3390 /$ su13179730

Academic Editors: Ermanno C. Tortia and Andrea Pérez

Received: 25 July 2021

Accepted: 26 August 2021

Published: 30 August 2021

Publisher's Note: MDPI stays neutral with regard to jurisdictional claims in published maps and institutional affiliations.

Copyright: (c) 2021 by the authors. Licensee MDPI, Basel, Switzerland. This article is an open access article distributed under the terms and conditions of the Creative Commons Attribution (CC BY) license (https:/ / creativecommons.org/licenses/by/ $4.0 /)$.

\begin{abstract}
The objective of the undertaken study is to investigate the sustainability of creative economy and present a case study providing the main findings on the linkages between creative economy and sustainable development. The in-depth literature review of the creative economy and sustainable development offered the main insights in the development of the case study hypotheses. A case study on the biggest music festival that was organised in Lithuania is provided. The findings confirm that creative economy can be environmentally sustainable, and the customers identified their clear preferences for sustainability criteria in music festivals; however, not all these preferences are properly addressed by the organisers of cultural events, as it was revealed by this case study. The results of a quantitative study show that the festival participants are increasingly expressing the need for sustainable music festivals, but organisers have not yet taken the necessary actions to address this need. It is likely that, in the near future, the festival organisers in Lithuania will have to start applying various sustainability criteria during the festivals in order to attract more visitors and generate more income from such events as well to ensure environmental safety. The practical implications of conducted study are equally important for all stakeholders, such as the community, policymakers, companies, and regulatory agencies that are concerned with the implementation of sustainable development practices.
\end{abstract}

Keywords: creative economy; creative industries; sustainable development; music festival; sustainability

\section{Introduction}

There is an extensive debate in scholarly literature that discusses the absence of linkages between the creative economy and sustainability (Jain, Jain, 2020 [1]; Pradhan et al., 2017 [2]; Streimikiene et al., 2019 [3]; Nocca, 2017 [4]; Brocchi, 2008 [5]).

According to (Streimikiene, Kacerauskas, 2020 [6]), the economic sustainability is related to the creative and cultural industries, and creativity promotes urban economic growth. The creativity policy is inseparable from the aim of sustainable development of cities and regions. The demand for more sustainable products and services is a result of both the "creative turn" and "green turn". However, the harmony between creativity, economic activity, and sustainability is not evident. On the contrary, these different aspects of human intentions are contradictory and have different outcomes.

However, the linkages between creativity, economic activity, and sustainability are full of contradictions and create many problematic issues. Though this relationship was analysed by several scholars (Streimikiene et al., 2019 [3]; Brocchi, 2008 [5]; Streimikiene, Kacerauskas, 2020 [6]; Rompay, Tineke, [7]; Leong et al., 2014 [8]; Kačerauskas, 2015 [9]; Howkins, 2009 [10]; Kačerauskas, 2016 [11]), it requires much more attention to support 
the decision making in promoting creative industries and enhancing their contribution to the sustainable development.

The analysis of links between the creative economy and sustainable development paradigm is complicated due to different definitions that appear in scientific discussions on paradigms of creativity and cultural economics. However, in a rapidly changing world, it is becoming difficult to define the areas of the economy that would not participate in the overall mechanism of the creative economy precisely. Thus, without a detailed description of the contribution of creative economy to the overall economy of a particular country or economic area, it is difficult to discuss how this economy can be linked to the criteria of sustainable development. Therefore, it is more appropriate not to analyse the generalised links between the creative economy and sustainable development but rather explore the individual performance in terms of sustainability of specific cultural and creative industries.

As it was mentioned in other scholarly works (Streimikiene, Kacerauskas, 2020 [6]), Lithuania has the highest share of cultural enterprises in non-financial business enterprises among the Baltic States, although Lithuania has the lowest ranking based on the main creativity indices. The value added, created by the cultural enterprises in the Baltic States, is smaller than the EU average (2.4\%). In Latvia, the value added, created by the cultural enterprises in 2018, made 1.8\%, in Estonia, 1.8\%, and in Lithuania, 1.6\% [3].

Therefore, this paper aims to clarify the gap based on the case study conducted in Lithuania. First, the literature on the creative economy in relation to sustainable development is provided by identifying the main problems.

Then, a case study on the biggest cultural event in Lithuania, i.e., the musical festival "Granatos Live", is presented for understanding the linkages between creative economy and sustainable development of a specific case. Though the creative economy includes a lot of cultural activities and phenomena, the case study on the musical festival "Granatos Live" was selected because of its high importance to the Lithuanian creative economy. There are eight popular live music festivals in Lithuania; however, "Granatos Live" is the most popular live music festival in Lithuania. It is constantly growing and has occurred regularly every year since 2015, and it has attracted more than 110,000 people in total. It creates many jobs and generates income, not only for the organisers but for many other market players as well. The festival organisers, by building on cultural heritage and using their creativity, pursue a wide variety of activities, ranging from cultural performances to the creative design of various souvenirs, festival attributes, catering, accommodation, transportation, etc.

The following hypotheses were formed for the case study:

Hypotheses 1 (H1). There is a positive correlation between the perception of the principles of sustainability and the assessment of sustainability of the musical festival.

Hypotheses $1 \mathbf{( H 2 )}$. There is a positive correlation between the disposable income and the requirements for principles of sustainable development at musical festivals.

\section{Literature Review on the Creative Economy and Sustainable Development}

In this section, the authors of the article analyse the main problems of creative economy in the context of sustainable development. The problems have been grouped according to their degree of abstractness. Firstly, the most general problems of creativity were presented (1-9) and then, the specific problems of creative industries (10-13). Issues 1-3 address the nature of creativity from a sustainable point of view. Issues 4 and 5 address the notion of social and creative capital with respect to sustainability. Issues 6-7 explore the axiology of sustainable creativity or, to be more precise, creative ethics (ecology) with sources of culture that are distinctive from the nature. Issues 8-9 examine the meta-sustainability, i.e., education of sustainability, as well as the idea of progress, from a sustainable point of view. Issue 10 continues the matter of distinction between the culture and nature but from the point of view of Creative Industry (CI). Issues 11-12 deal with such aspects of CI as 
technologies and dynamism. Issue 13 returns to a meta-question of creativity uniqueness but with respect to CI. Table 1 presents a summary of conducted analyses. It should be noted that the description and the numeration are the same. In the literature review, the authors of the article used Clarivate Analytics Web of Science platform. The main criteria for selecting papers were the citation time and the publication date (the priority was given to recent publications). By defining the problems, the authors used methods of contrast. In this case, the authors contrasted the ideas of creative economy and the ideas of sustainable development.

Table 1. The problems of creative economy from sustainable development point of view.

\begin{tabular}{|c|c|c|c|c|}
\hline No. & Issues: Creative Economy & $\begin{array}{l}\text { Issues: Sustainable } \\
\text { Development }\end{array}$ & Problems and Questions & Sources \\
\hline 1. & $\begin{array}{l}\text { Creativity inseparable from } \\
\text { certain uncertainty }\end{array}$ & $\begin{array}{c}\text { Uncertainty as an aspect of } \\
\text { unsustainability }\end{array}$ & $\begin{array}{l}\text { Does creativity increase the } \\
\text { economic uncertainty? }\end{array}$ & $\begin{array}{l}\text { Galazova, } 2016 \text { [12]; } \\
\text { Caves, } 2002 \text { [13]; }\end{array}$ \\
\hline 2. & $\begin{array}{c}\text { Creativity associated with } \\
\text { destruction and } \\
\text { disequilibrium }\end{array}$ & $\begin{array}{c}\text { Destruction and } \\
\text { disequilibrium associated } \\
\text { with unsustainability }\end{array}$ & $\begin{array}{l}\text { How to harmonize creative } \\
\text { destruction and sustainable } \\
\text { development? }\end{array}$ & $\begin{array}{l}\text { Hart, Milstein, } \\
\quad 1999[14]\end{array}$ \\
\hline 3. & $\begin{array}{l}\text { Creativity appeals to a } \\
\text { utopian society or "imagined } \\
\text { community" }\end{array}$ & $\begin{array}{l}\text { Is the utopian character of } \\
\text { creative society a factor of } \\
\text { sustainability? }\end{array}$ & $\begin{array}{c}\text { Which scenario (optimistic or } \\
\text { pessimistic) of sustainable } \\
\text { development is real? }\end{array}$ & $\begin{array}{l}\text { Anderson, } 1991 \text { [15]; } \\
\text { Florida, } 2002 \text { [16] }\end{array}$ \\
\hline 4. & $\begin{array}{l}\text { The idea of creative } \\
\text { sustainability follows from } \\
\text { the idea of creative capital }\end{array}$ & $\begin{array}{l}\text { The factors of social } \\
\text { sustainability are creative } \\
\text { clusters and artistic } \\
\text { community }\end{array}$ & $\begin{array}{l}\text { Are social sustainability and } \\
\text { creative sustainability } \\
\text { contradictory notions? }\end{array}$ & $\begin{array}{l}\text { Tönnies, } 1957 \text { [17]; } \\
\text { Florida, } 2002 \text { [16] }\end{array}$ \\
\hline 5. & $\begin{array}{l}\text { From an economic point of } \\
\text { view, natural and cultural } \\
\text { capitals are parallel }\end{array}$ & $\begin{array}{l}\text { Culture ignores and destroys } \\
\text { the exploitation of nature, } \\
\text { which is inseparable from the } \\
\text { economic activity }\end{array}$ & $\begin{array}{c}\text { How to harmonize cultural, } \\
\text { economic and ecologic } \\
\text { approaches? }\end{array}$ & Throsby, 2015 [18] \\
\hline 6. & $\begin{array}{l}\text { Green environment demands } \\
\text { creative performance }\end{array}$ & $\begin{array}{l}\text { Unconditional and unlimited } \\
\text { creativity leads to the } \\
\text { destruction of entire social or } \\
\text { natural systems }\end{array}$ & $\begin{array}{c}\text { What is the content of } \\
\text { creative ethics and creative } \\
\text { ecology? }\end{array}$ & $\begin{array}{l}\text { Rompay, Tineke, } \\
2016 \text { [7]; Leong et al., } \\
2014 \text { [8] }\end{array}$ \\
\hline 7. & $\begin{array}{l}\text { The "culture-centric" and } \\
\text { "economic-centric" } \\
\text { approaches are dominant }\end{array}$ & $\begin{array}{l}\text { Culture has been treated as } \\
\text { an antipode of nature, while } \\
\text { traditional economic activity } \\
\text { has been understood as } \\
\text { exploitation of nature }\end{array}$ & $\begin{array}{l}\text { What about synergies } \\
\text { between cultural creativity } \\
\text { and natural greenery? }\end{array}$ & $\begin{array}{c}\text { Andres, Chapain, } \\
2013 \text { [19]; Stolarick, } \\
\text { Smirnova, } 2015 \text { [20]; } \\
\text { Kozima et al., } 2019 \text { [21] }\end{array}$ \\
\hline 8. & $\begin{array}{l}\text { Creativity is hardly formed } \\
\text { in the process of education }\end{array}$ & $\begin{array}{l}\text { Learning and education are } \\
\text { crucial for sustainable } \\
\text { development }\end{array}$ & $\begin{array}{l}\text { What is the relationship } \\
\text { between education, creativity } \\
\text { and sustainability? }\end{array}$ & $\begin{array}{l}\text { Voytenko et al., } \\
2016 \text { [22] }\end{array}$ \\
\hline 9. & $\begin{array}{l}\text { Not prescriptive and not } \\
\text { quantitative nature of } \\
\text { creativity }\end{array}$ & $\begin{array}{c}\text { The idea of progress ignores } \\
\text { issues of natural } \\
\text { sustainability }\end{array}$ & $\begin{array}{l}\text { How to harmonize the } \\
\text { ideology of efficiency and } \\
\text { progress with the idea of } \\
\text { sustainable development? }\end{array}$ & $\begin{array}{c}\text { Ellul, } 1964 \text { [23]; Dewey, } \\
1930 \text { [24] }\end{array}$ \\
\hline 10. & $\begin{array}{l}\mathrm{CI} \text { accelerate the economic } \\
\text { growth in general }\end{array}$ & $\begin{array}{l}\text { Contradiction between } \\
\text { capitalistic system to be } \\
\text { continually expanded and } \\
\text { the finite natural and human } \\
\text { resources }\end{array}$ & $\begin{array}{l}\text { Does it mean that creative } \\
\text { industries contribute to the } \\
\text { exploitation of natural } \\
\text { resources? }\end{array}$ & $\begin{array}{l}\text { Böhm et al., } 2012 \text { [25]; } \\
\text { Magdoff, Foster, } \\
2010 \text { [26]; Cooke, } \\
\text { Propris, } 2011 \text { [27] }\end{array}$ \\
\hline 11. & $\begin{array}{l}\text { CI are the accelerators or } \\
\text { even the results of } \\
\text { modernization }\end{array}$ & $\begin{array}{l}\text { Society and nature are } \\
\text { threatened by the } \\
\text { modernization process itself }\end{array}$ & $\begin{array}{c}\text { Does it mean that people will } \\
\text { have more and more risks } \\
\text { after technologies and } \\
\text { culture merge? }\end{array}$ & $\begin{array}{c}\text { Werner, } 2005 \text { [28]; } \\
\text { Jonas, } 1985 \text { [29]; } \\
\text { Giddens, } 1991 \text { [30]; } \\
\text { Beck, } 1992 \text { [31]; } \\
\text { Bourdieu, } 2011 \text { [32] } \\
\text { Cucuzzella, } 2016 \text { [33] }\end{array}$ \\
\hline
\end{tabular}


Table 1. Cont.

\begin{tabular}{ccccc}
\hline No. & Issues: Creative Economy & $\begin{array}{c}\text { Issues: Sustainable } \\
\text { Development }\end{array}$ & Problems and Questions & Sources \\
\hline 12. & $\begin{array}{c}\text { Creative industries are } \\
\text { dynamic }\end{array}$ & $\begin{array}{c}\text { Sustainable development is } \\
\text { hardly possible under the } \\
\text { conditions of dynamism }\end{array}$ & $\begin{array}{c}\text { Does it mean that CI are the } \\
\text { factors of unsustainability } \\
\text { because of their dynamism? }\end{array}$ & Dursun, 2018 [34] \\
13. & $\begin{array}{c}\text { CI intensify the global } \\
\text { economic system }\end{array}$ & $\begin{array}{c}\text { Globalization and } \\
\text { internationalization } \\
\text { contribute to the economic } \\
\text { growth more than ecological } \\
\text { movement }\end{array}$ & $\begin{array}{c}\text { As the agents of } \\
\text { globalization, CI lose their } \\
\text { uniqueness and creativity }\end{array}$ & Dursun, 2018 [34]; \\
\hline \multicolumn{4}{c}{ Source: compiled by the authors. }
\end{tabular}

1. Creative initiative provides a competitive economic advantage. Conversely, creativity means uncertainty with respect to the final product and the demand for it in the free market (Galazova, 2016 [12]). (Caves, 2002 [13]) refers to it as the principle of "nobody knows", i.e., nobody knows about either the impact on a product to be created or the future success of this product. This uncertainty, as well, covers the sphere of (un)sustainable economic development.

2. Creativity is associated with destruction and disequilibrium (Hart, Milstein, 1999 [14]). However, without macro-creativity, no social change, including the change from the Coal (Oil) Age to the Knowledge Age and finally to the Creative Age, is possible. The question is how to harmonise these dramatic economic and social transformations with an agenda of sustainable development?

3. The creative class or even creative society presupposes an "imagined community" (Anderson, 1991 [15]). For example, (Florida, 2002 [16]) mentions that the members of the creative class are not sufficiently conscious as such. Similarly, the issue of members of creative society that need both responsibility and creative intentions can be discussed. In this context, the question arises whether an imagined community is real if it opens such important implications for social sustainability.

4. It seems that social sustainability is the reverse side of social capital, the aspect of which is a Community (Tönnies, 1957 [17]). If this is true, what does this tell about the conflict between social capital and creative capital (Florida, 2002 [16])? What about creative sustainability? If it contradicts social sustainability, then what about creative clusters and the artistic community? Finally, if creative sustainability eliminates social sustainability, what can it be said about the region of moral and sustainability values shared in (imagined or not) community?

5. Some scholars (e.g., Throsby, 2015 [18]) treat natural and cultural capital as being in parallel because they connect cultural and economic values. However, culture has been defined as a contrast to nature, as it has been mentioned previously. Indeed, throughout history, culture has ignored and destroyed nature with economies that are increasingly dependent on the exploitation of natural resources.

6. Scholars argue that the protection of the environment requires a creative performance (Rompay, Tineke, 2016 [7]), which is associated with an innovative and holistic approach (Leong et al., 2014 [8]). Yet, it does not always follow that creative activity is necessarily ecological and/or sustainable. On the contrary, unconditioned and unlimited creativity can lead to the destruction of entire social or natural systems, which is why the creative ethics (Kačerauskas, 2015 [9]) and creative ecology are discussed (Howkins, 2009 [35]; Kačerauskas, 2016 [36]; Kačerauskas, 2017 [37]).

7. The "culture-centric" and "economic-centric" (Andres, Chapain, 2013 [19]) approach does not ensure the ecological perspective of sustainability. As mentioned, historically, culture has been treated as an antipode of nature, and traditional economic activity has been understood as the exploitation of nature. As a result, the question on synergies 
between creativity and greenery (Stolarick, Smirnova, 2015 [20]; Kozina et al., 2019 [21]) is still open.

8. Although learning and education are crucial for sustainable development [24]; for both strategy makers and strategy users, creativity is not formed in the process of education, despite the importance of creative schools in different areas.

9. There appears to be a problem with the methods that are applied in the following section. (Ellul, 1964 [23]) and (Dewey, 1930 [24]) noted the quantitative and semiquantitative methods based on computable data that are relatively easy to rationalise and were favourable to support their judgments. However, "Can creativity exist in a prescriptive and quantitative environmental methodology"? (Cucuzzella, 2016 [33]). Namely, quantitative predictivity does not allow seeing the catastrophic consequences of natural pollution, which is the result of consumer culture. The notion of unconditional progress and the ideology of efficiency are supported by the rational intention to rely on blind, computable data. By ignoring this problem, the enthusiasts of creative industries (Howkins, 2001 [10]) and creative class (Florida, 2002 [16]) rely too heavily on the ideology of economic and technological efficiency.

10. The scholars (Böhm et al., 2012, [25]; Magdoff, Foster, 2010 [26]) acknowledge the contradiction between the constantly expanding capitalistic system and the world's finite natural and human resources. However, some scholars (Cooke, Propris, 2011 [27]) stress that the creative industries accelerate economic growth in general. Does this mean that creative industries contribute (albeit indirectly) to the exploitation of natural resources?

11. According to some scholars (Werner, 2005 [28]; Jonas, 1985 [29]; Giddens, 1991 [30]; Beck, 1992 [31]; Cucuzzella, 2016 [33]), society is endangered by the risks associated with the process of modernisation. If creative industries are the accelerators or even the results of modernisation, does this mean that even greater risk must be managed when technologies are merging with culture? One aspect of this risk is its existence as a cultural unifier, even the loss of creativity in the media under the conditions of rating thinking (Bourdieu, 2011 [32]).

12-13. Some authors consider that "it is very difficult to provide sustainable development in those cultural industries because of their dynamicity" (Dursun, 2018: 2 [34]). In the context of internationalisation and globalisation, the following paradox is encountered: creative industries are called to intensify the global economic system; yet, they lose their uniqueness and creativity under the conditions of global unification that touches economic, as well as cultural and political, sides of the unified system.

The problems and questions mentioned in Table 1 could be summarised by grouping them into the main categories. First, there is a contradiction between creative and sustainable economic development, since creative development means economic uncertainty and sustainable development is oriented towards the economic harmony. Secondly, people face different aspects of their life beyond economy, including culture, ecology, ethics, and education. The question arises how to harmonize the different approaches? Thirdly, there is a contradiction between the ideology of progress and the idea of sustainable development.

In short, harmony between creativity, economic activity, and sustainability is not evident. In fact, these different aspects of human intentions are contradictory. However, the sustainability of creative economy can be evaluated based on the concrete practical case study.

There is a connection between the creative economy and the investigated case study (it seems to be a weak connection between the overall concept of creative economy and these cultural events). There can be a connection created between creative economy (as a holistic approach) and cultural events (the creative economy includes a lot of activities and cultural phenomenon).

\section{Background of the Case Study}

At the 74th session of the UN General Assembly, 2021 was declared as the International Year of Creative Economy for Sustainable Development (United Nations, 2019) [38]. The 
document [38] states that the creative economy is seen as an "orange economy" based on the knowledge-based economic activities. Thus, at the declarative level, it is already clear that the creative economy is linked to the pursuit of sustainable development goals: job creation, contributing to the preservation and upgrading of cultural heritage, promoting sustainable tourism, promoting sustainable consumption, and other issues that are important for all humankind.

Music festivals, depending on their size, generate large cash flows and provide high input to the creative economy. It is often more important for organisations to reap financial benefits than pay more attention to the implementation of the principles of sustainable development at the events. However, organisations should monitor the negative effects of their events on nature more precisely. They should be able to recognise them and manage them when needed (Bowdin et al., 2006) [39]. Bowdin et al. (2006) [39] emphasize that certain events can inspire, increase awareness, and encourage participation in sport or cultural activities. Other events broaden the cultural horizon, inspire new ideas, and cultivate customs. The examples of such festivals are those that reflect the history, traditions, or culture of own or other nations. Some activities may as well lead to the exploration of opportunities, especially those that represent an issue of national or global importance and thus alert the public.

The UK's Sustainable Festivals Initiative (Powerful thinking, 2015) [40] provides an opportunity to talk about how the elements of sustainable development can be promoted during festivals:

- Reduced water consumption,

- Waste reduction,

- Environmentally friendly food and drink,

- $\quad$ Positive investments and initiatives.

These initiatives and measures are taken in order to meet expectations. For example, the organisers of Coachella Valley Music and Arts Festival say that, during the festival, they are educating employees and other stakeholders, talking about the need for sustainable development and everyone's contribution to the sustainability. They work with those partners who support the pursuit of sustainable development as well. The aim is to minimize the use of plastics, promote sorting, involve local community, and adhere to other principles of sustainable development. In the UK, there is an initiative to promote the implementation of principles of sustainable development during the music festivals until 2025. The report, based on 279 UK summer music festivals, found that the industry is responsible for approximately 20 kilotonnes of $\mathrm{CO}_{2} \mathrm{e}$ annually (onsite emissions), 100 kilotonnes $\mathrm{CO}_{2} \mathrm{e}$ annually, including audience travel, 23,500 tonnes of waste, 5 million litres of diesel consumption. It has been noticed that more and more visitors of music festivals are interested in the implementation of sustainable development goals during the festival [40].

The United Nations Music and Environment Initiative [41] aims to provide an overview of the global music industry in relation to sustainable development. The initiative document identified three main obstacles in the music industry for becoming a sustainable, cohesive festival. First is a lack of knowledge, limited funding, and limited opportunities for skilled workers. Second is the lack of environmental friendliness in the music industry. Thirdly, transport, electricity consumption and waste generation are still considered the biggest problems. The aim of this initiative is to help reduce the skills and knowledge gaps on environmental issues and create networks and campaigns focused on sustainable opportunities (Scanlon, 2010) [42].

In order to study how the principles of sustainable development are implemented during the festivals, certain indicators are singled out in the scientific literature, which allow us to assess how, and to what extent, the principles of sustainable development are implemented. However, in order to assess this, the initiatives, such as the UK Sustainable Festivals Initiative [40], which allows for the evaluation of festival sustainability initiatives, are needed. In the absence of such initiatives, it becomes difficult to assess the sustainability 
of the festival. The question is how to assess the sustainability of a music festival if only some criteria are known, but there is no data to assess the criteria. The case study provided below is based on the qualitative case analysis and quantitative research data, having in mind, that no one has ever evaluated music festival sustainability criteria in Lithuania. Before the pandemic period, Lithuania hosted many festivals of various music genres, organised both in open spaces and indoors. It is important to note that in Lithuania, the official statistics do not take into account either the contribution of creative economy to the overall economy or the economic value of creative industries to the overall economy.

\section{Description of the Case Study}

One of the largest and most popular music festivals in Lithuania "Granatos Live" was selected for the case study. According to the festival organisers, the annual audience is composed of about 20,000 participants who attend this music festival. The festival, which is growing every year, has been visited by almost 110,000 participants during 7 years [43]. In terms of the number of participants, it can be seen that the festival involves a significant number of participants; thus, this undoubtedly has an impact on the surrounding environment, in terms of the geographical area and the participants in the event itself. It is, as well, important to mention that there are no official statistics on the flow of visitors to the music festivals. The ticketing data to estimate the visitor flows is not available in the official statistics. The Lithuanian Music Information Center and the Lithuanian Association of Creative Industries, as well, do not have such data.

The official website of the festival [43] announces that "Granatos Live" is a festival of music and active entertainment, which has been held annually since 2013 in the territory of the Lithuanian Folk Museum in Rumšiškès. The festival takes place in the heritage area. It is the only live music festival that is organised in the territory of the Lithuanian Ethnographic Museum of Cultural Heritage.

"Granatos Live" is organised in the territory of the Lithuanian Folk Museum. The museum is open-air. The official website of this museum states that "The Lithuanian Folk Museum is one of the largest open-air museums in Europe in terms of area (195 ha) and number of real exhibits. The main immovable units of the exposition are homesteads of farms of various wealth or their fragments" [44]. It should be mentioned that the vast majority of the museum exhibits are wooden architectural homesteads. Thus, the chosen case study is unique in Lithuania, as the music festival "Granatos Live" is organised in the protected territory of the museum. Although the area of the museum is large, in terms of sustainable development, such an event can have negative consequences for the protected area of the museum as a single space.

The "Granatos Live" festival website contains rules for festival participants prohibiting bringing psychotropic substances, alcoholic beverages, glass containers, weapons, pyrotechnics, and grills into the festival area. There are clauses in the rules that take into account the protection of the environment and the preservation of historical heritage. It is forbidden to destroy and damage museum exhibits, natural objects, arbitrary felling and destruction of trees, bushes, flowerbeds, anthills, or bird nests, endanger the safety or life of other persons, litter, and pollute the environment. It is strictly forbidden to smoke in and near the territories of all exhibits (meetings) of the Lithuanian Folk Museum. It is forbidden to be in the territories of all exhibits (meetings) of the Lithuanian Folk Museum during the dark time of day [43]. It is warned that intoxicated persons may be expelled from the festival grounds. It is forbidden to create fireplaces in and around the festival territory. The festival as well declares to be environmentally friendly and encourages festival participants not to litter. These festival rules partially reflect the social and environmental orientation of the festival. It is also necessary to stress that this music festival was chosen for the case study because of the fire that took place during the festival in 2017, which had negative consequences to the Lithuanian Folk Museum, as two exhibits of the Lithuanian Folk Museum were burned down completely during the fire. The property damage caused to the state during the fire festival "Granatos Live 2017" is estimated at almost 208 thousand 
euros; however, it is hard-to-calculate the loss of Lithuanian cultural heritage that was made. During the court proceedings, it was not clear what caused the fire. Despite all these circumstances, the music festival "Granatos Live" is still organised in the territory of the Lithuanian Folk Museum.

Summarizing this case, it can be stated that the festival organisers do not declare or voluntarily encourage participants to adhere to the principles of sustainable development during the festival. The safety rules of the participants are observed as well as minimal care for the environment and territory. The risk that a similar case, involving the loss of cultural heritage values during the festival, may reoccur still remains. The global experience of organizing music festivals before the pandemic has shown that music festivals seek to declare and adhere to the principles of sustainable development and educate participants on sustainable development issues during the festival. For example, the Coachella Valley Music and Arts Festival website talks about sustainable development and points out the contribution that the organisers of this festival, together with the festival community, are making, and can make, for achieving sustainability [45]. Both the case study and the development trends of global music festivals show that the organisers of the music festival "Granatos Live" must build on global good practice and seek to contribute to the implementation of the principles of sustainable development.

\section{Methodology}

\subsection{Presenting the Questionnaire}

The object of the quantitative assessment that is based on a survey of festival participants is the valuation of sustainability of the festival "Granatos Live" from the point of view of the participants. Therefore, the aim of this case study is to assess the sustainability of a music festival from the perception of its participants and test hypotheses provided in the introduction of this paper.

A quantitative study, using a survey method, is described further. The questionnaire consisted of three blocks of questions. The first block was designed to identify sociodemographic characteristics. The second block of questions was designed to examine the respondents' attitudes and knowledge on sustainable development. The third block of questions was devoted to the evaluation of the implementation of principles of sustainable development during "Granatos Live" music festival from the participants' point of view.

The questionnaire consisted of closed questions. A 5-point Likert scale was used to identify the knowledge of principles on sustainable development and respondents attitudes towards sustainable development.

A 5-point Likert scale was as well used to evaluate the principles of sustainable development that were applied by the music festival under study.

Before analysing the data, the internal consistency of the questionnaire questions and the questions with the Likert scale that were used to test the hypotheses were checked (Table 2). According to V. Pakalniškienè (2012) [46], the internal consistency of the data shows whether the properly designed questions and data are reliable for further analysis. The Cronbach's alpha is used to show this indicator. With values greater than 0.7, the questionnaire is considered consistent and valid. 
Table 2. Internal consistency analysis of the entire questionnaire and questions with a Likert scale to test the hypotheses.

\begin{tabular}{ccc}
\hline & Cronbach's Alpha & Number of Variables \\
\hline Questionnaire & 0.937 & 25 \\
\hline $\begin{array}{c}\text { Statements on the understanding of } \\
\text { principles of sustainable development } \\
\text { and statements about respondents" } \\
\text { sustainable habits }\end{array}$ & 0.846 & 11 \\
\hline $\begin{array}{c}\text { Statements on the application of } \\
\text { principles of sustainable development } \\
\text { during the "Granatos Live" festival }\end{array}$ & 0.860 & 14 \\
\hline
\end{tabular}

Source: compiled by the authors according to the data of the SPSS output window.

\subsection{Survey Sample and Organisation of the Study}

Survey sample. Prior to the pandemic, in 2017-2020, about 20,000 participants visited the analysed festival on average per year. The sample is calculated by using the Paniotto formula with 5 percent of error. The size of the sample is 377. During the research, 386 festival participants were interviewed. Therefore, it can be stated that the received answers are sufficient to represent the opinion of the festival participants. After evaluating the reliability of the received answers, $381(n=381)$ were selected for the analysis.

Organization of the study. The survey was organised in October 2020. The prepared questionnaire was placed on the electronic survey portal, and the link to the questionnaire was distributed on social networks, asking the participants of music festival "Granatos Live" to answer the questions as well as share the link with other survey participants.

The person who is responsible for cultural events in Kaunas City Municipality was introduced to the results of the research, and the application of principles of sustainability during the music festivals was discussed. The person did not want his or her personal data to be published. Therefore, in the text, the person is referred to as Interviewer X.

\subsection{Results}

Firstly, the socio-demographic profile of the respondents is analysed. A detailed frequency of respondents according to the socio-demographic characteristics is presented in Table 3.

The analysis of the gender frequency of respondents shows that females are more likely to participate in the research than males. The age frequency of respondents indicates that 41 and older individuals were the least likely to participate in the study. A small number of individuals under 18 years were also included in the research. The majority of respondents in the survey indicated that they were students or employed persons. The monthly income of respondents varied from 400 Euros per month to 2001 Euros and more per month. It can be stated that, during the research, the respondents of different gender, age, and social status, with different amounts of monthly income, were interviewed.

The study examined the respondents' attitudes towards sustainable development and sustainable behaviour (see Table 4). 
Table 3. Characteristics of quantitative survey respondents (number and \%).

\begin{tabular}{|c|c|c|c|}
\hline & Characteristics & $\begin{array}{l}\text { Number of } \\
\text { Respondents }\end{array}$ & Respondents in \% \\
\hline & Total: & 381 & 100 \\
\hline \multirow{3}{*}{ Gender } & Female & 224 & 58.79 \\
\hline & Male & 157 & 41.21 \\
\hline & Other, prefer not to specify & 0 & 0 \\
\hline \multirow{6}{*}{ Age } & Under 18 & 45 & 11.7 \\
\hline & $18-25$ years & 86 & 22.6 \\
\hline & $26-30$ years & 94 & 24.7 \\
\hline & $31-35$ years & 97 & 25.5 \\
\hline & $36-40$ years & 43 & 11.3 \\
\hline & 41 and more & 16 & 4.2 \\
\hline \multirow{5}{*}{ Education } & Lower secondary & 42 & 11 \\
\hline & Upper secondary & 91 & 23.9 \\
\hline & Vocational & 59 & 15.5 \\
\hline & Higher & 86 & 22.6 \\
\hline & University & 103 & 27 \\
\hline \multirow{5}{*}{ Social status } & Pupil & 44 & 11.6 \\
\hline & Student & 128 & 33.6 \\
\hline & Unemployed & 65 & 17 \\
\hline & Employed & 144 & 37.8 \\
\hline & Other & 0 & 0 \\
\hline \multirow{6}{*}{ Monthly income } & Less than 400 Eur & 72 & 18.9 \\
\hline & 401-700 Eur & 86 & 22.6 \\
\hline & 701-1000 Eur & 137 & 36 \\
\hline & 1001-2000 Eur & 42 & 11 \\
\hline & 2001 Eur and more & 41 & 10.7 \\
\hline & Prefer not to specify & 3 & 0.8 \\
\hline
\end{tabular}

Source: compiled by the authors according to the empirical research data.

Table 4. Distribution of respondents' opinions on issues of sustainable development and sustainable behaviour (\%).

\begin{tabular}{|c|c|c|c|c|c|}
\hline Questions & Always & Often & Sometimes & Rarely & $\begin{array}{l}\text { Very Rarely or } \\
\text { Never }\end{array}$ \\
\hline In my daily life I am sorting garbage (sorting garbage habits) & 9.4 & 19.9 & 28.2 & 24.7 & 17.8 \\
\hline I am trying to minimize self-consumption & 9.8 & 21.4 & 26.3 & 24.4 & 18.1 \\
\hline $\begin{array}{l}\text { I am interested in sustainable development aspects (social, } \\
\text { economic, environmental) }\end{array}$ & 17.4 & 23.2 & 46.3 & 11.3 & 1.8 \\
\hline $\begin{array}{l}\text { I am searching for information about climate change issues, } \\
\text { so I think that I am interested in climate change issues }\end{array}$ & 15.6 & 48.3 & 26.3 & 7.6 & 2.2 \\
\hline $\begin{array}{l}\text { When I am buying food, clothes, cosmetics, etc., I prefer } \\
\text { environmentally friendly products }\end{array}$ & 7.3 & 14.3 & 38.3 & 24.6 & 15.1 \\
\hline $\begin{array}{l}\text { I prefer to use environmentally friendly transport (public } \\
\text { transport, bicycle, scooter, electric car, etc.) }\end{array}$ & 8.7 & 16.3 & 39.4 & 18.2 & 17.4 \\
\hline
\end{tabular}


The distribution of opinions in response to the questions that were asked is discussed below.

One of the questions revealed how often respondents sort garbage in their daily lives. The majority of respondents of the survey stated that they sometimes sort garbage. Some respondents stated that they are sorting rarely or very rarely. With this frequency of data, the research examined whether the age of respondents correlated with sorting habits. It has been found that individuals who fall into the 26-30 age category tend to be sorting always or frequently: 78 percent of respondents in this age category stated that they always or most often are sorting garbage.

The next research question was addressed to examine the consumption reduction practices. The data has shown that participants of the festival tend to reduce their consumption in most cases. Only the intensity of consumption reduction differs.

The analysis of the survey data showed that working females with a monthly income of 2001 and more tend to reduce their consumption the most. These women have higher education and are from 31 to 35 years old. Women, who in the study indicated that they have a monthly income from 401 to 700 Euros, are the least likely to minimise their consumption. These females fall into the 18-25 age category.

The survey sought to determine whether respondents were interested in sustainable development issues.

Without analysing the distribution of respondents according to the socio-demographic parameters, it can be stated that the majority of respondents are sometimes interested in the principles of sustainable development (46.3\%).

An in-depth statistical analysis of the data revealed that those with a monthly income of 2001 and higher were mostly interested in the principles of sustainable development. These individuals are employed and are from 26 to 30 years old. The constant interest in the principles of sustainable development does not depend on gender.

The survey found that respondents were more interested in climate change issues than the principles of sustainable development. In fact, 63.9 percent of respondents said they were constantly or frequently interested in climate change. Such frequency of data can as well be related to the information channels available to respondents. In Lithuanian media, climate change issues are analysed and discussed quite often. The aspirations and principles of sustainable development are analysed in the media only sometimes. For example, Google search in Lithuanian for "sustainable development" returns 213,000 results in 0.37 s. The Lithuanian phrase "climate change" in Google search shows 814,000 results in $0.44 \mathrm{~s}$.

The next question was about choosing environmentally friendly products. It was important to determine how often respondents choose environmentally friendly products. The respondents were asked to indicate how often they choose environmentally friendly clothing, household items, cosmetics, and other products. This article presents only generalised data showing the frequency of selection of environmentally friendly products.

The data has shown that 22 percent of respondents always or often choose environmentally friendly products. Given that a large proportion of respondents have only a medium-sized monthly income, this indicator shows that the participants of "Granatos Live" music festival, who participated in the survey, tended to choose a variety of environmentally friendly products. It is important to mention that 38.3 percent said that they sometimes choose environmentally friendly products. Such frequency of data allows us to state that not only the interest in environmentally friendly products is growing in Lithuania, but the consumption of such products as well. Although, the reduction in consumption can still be perceived as an unsolvable problem. A correlation was found between education and environmentally friendly product selection. The correlation coefficient is 0.735 .

One of the principles of sustainable behaviour on an individual level is the choice of sustainable transport. The research tried to determine how often respondents choose environmentally friendly transport as an option. The environmentally friendly transport 
included such categories as hybrid or electric cars, public transport, cycling, or scooter travel.

The obtained data show that the respondents choose environmentally friendly transport. However, it should be noted that only a quarter of all respondents always or often choose environmentally friendly transport. In fact, 39.4 percent say that they choose such transportation sometimes. This frequency of data shows that, if possible, young people in Lithuania choose environmentally friendly transport. The study examined only the tendencies of environmentally friendly transport choices, but not the regularity of such transport choice and use or the reduction in polluting transport.

The respondents were also asked to express their views on how they and the people around them should live if they followed the principles of zero waste. The respondents were asked to evaluate five key principles of zero waste, where 5 means strongly agree and 1 means strongly disagree. Results are plotted in Figure 1.

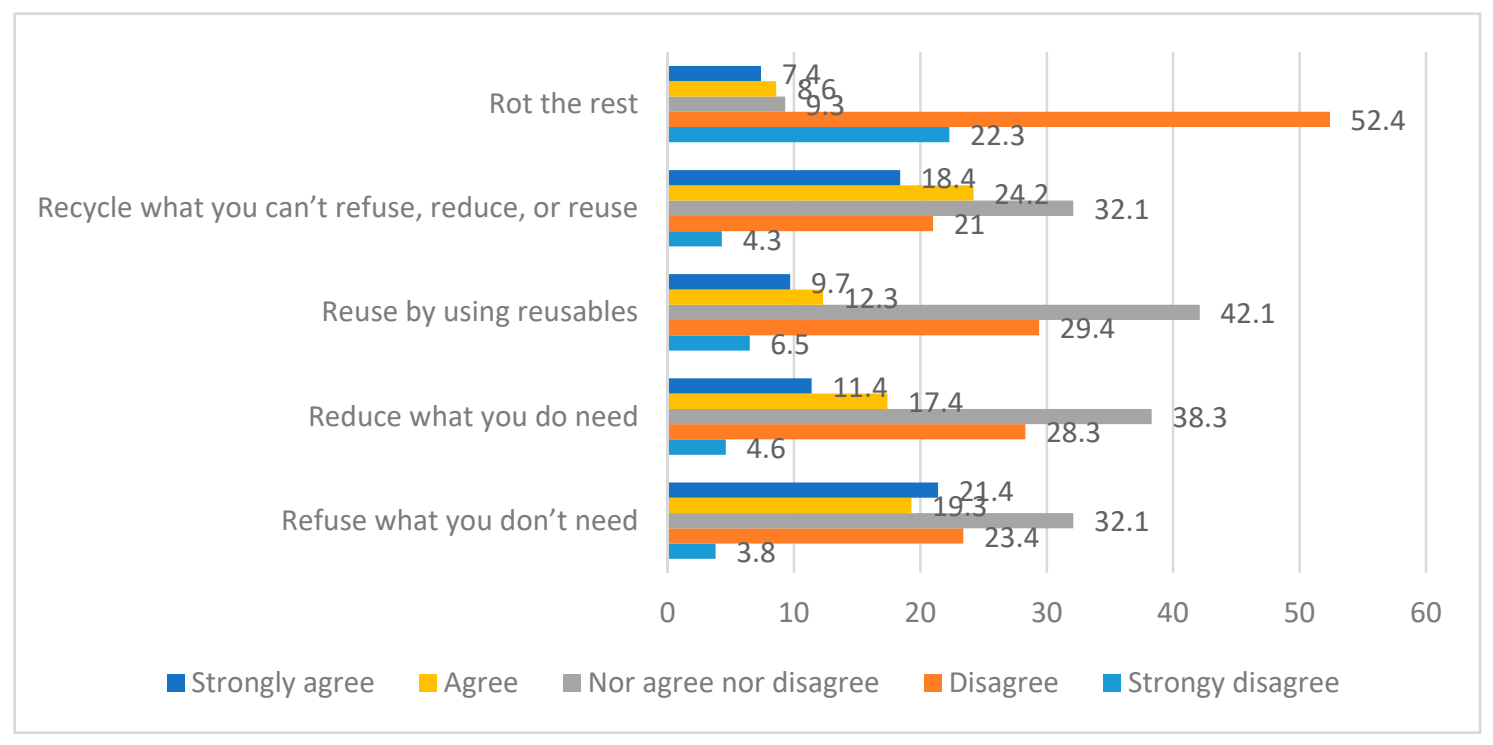

Figure 1. Attitudes towards Zero Waste. Source: compiled by the authors according to the empirical research data.

The data show that most respondents tend to think that it is enough to follow the principle of zero waste "Refuse what you do not need". The zero waste principles themselves are treated very differently. It should be noted that in fact, the principle of "rot the rest" is difficult to implement when living in the urban areas, i.e., in the apartments. The answers of respondents, which are related to ignorance, neutral position, dominate.

Overall, when assessing the respondents' position on sustainable development issues, it should be noted that young people tend to be interested in sustainable development, climate change issues, having in mind that participants of this festival are young people, in terms of this research data.

The survey found that respondents were more interested in climate change than in the principles of sustainable development. It is, so far, dominated by a weak positive assessment of zero waste philosophy as a way of life. It should be mentioned that the respondents try to choose environmentally friendly products and environmentally friendly transport. Taken as a whole, these trends show that respondents are concerned with the integration of principles of sustainable development into the music festivals.

The third block of questions was related to the assessment of sustainability of the festival. The respondents were asked to rate whether the festival "Granatos Live" is sustainable, given in mind the fact that the festival is organised in a protected area. Actually, 27.8 percent said the festival is unsustainable or completely unsustainable, given that it is organised in a special, protected area of the open-air museum. However, 56.4 percent of respondents thought that the festival is sustainable, even though organised in a protected 
area, because the organisers take full responsibility. Only 15.8 did not have a strong position and could not say whether the festival is harmonious, sustainable or incoherent, or unsustainable, when it is organised in a protected area.

During the research, it was important to determine how respondents assess the overall sustainability of the festival "Granatos Live". Results are plotted in Figure 2.

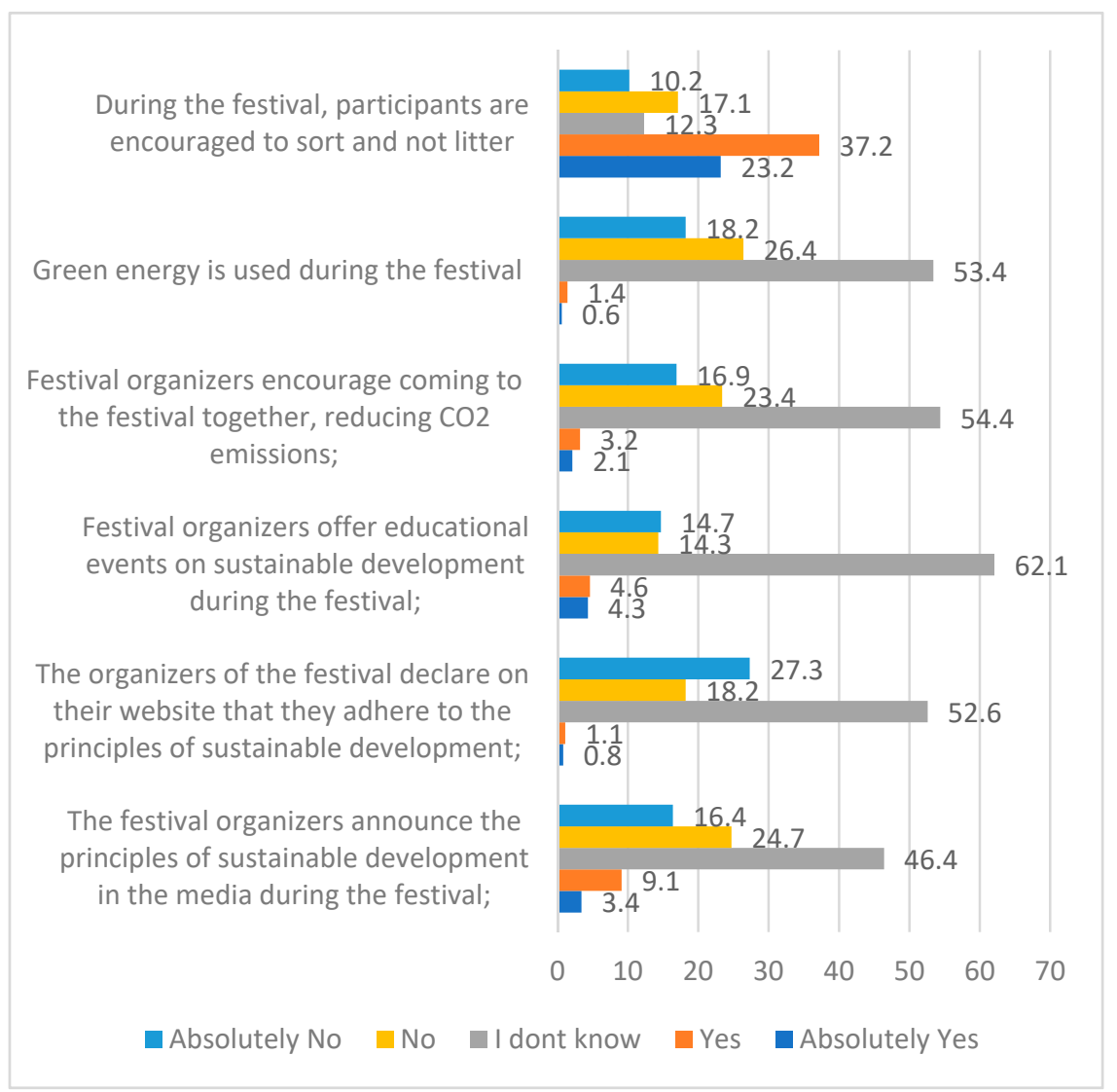

Figure 2. Assessment of sustainability of "Granatos Live" festival. Source: compiled by the authors according to the empirical research data.

Respondents, when providing answers about the application of principles of sustainable development during the festival, basically indicated that the organisers of the festival do not declare and do not apply the principles of sustainable development during the festival. The participants of the festival are only encouraged to sort and not litter. This distribution of the data, provided by the respondents, coincides with the initial case analysis performed by the authors of this article. The study found a strong correlation between the individuals who try to choose sustainable transport in their daily lives (question from the second block of the questionnaire) and those who believe that festival organisers do not encourage coming to the festival together, thus contributing to the $\mathrm{CO}_{2}$ reduction. The correlation coefficient is 0.754 . It can be argued that sustainable daily choices correlate with the assessment of sustainability of the festival.

The next research question was dedicated to determine whether it was important for the respondents to adhere to the principles of sustainable development during the music festival. The respondents were asked whether the scope of application of the principles of sustainable development is important when choosing a music festival. Results are plotted in Figure 3. 


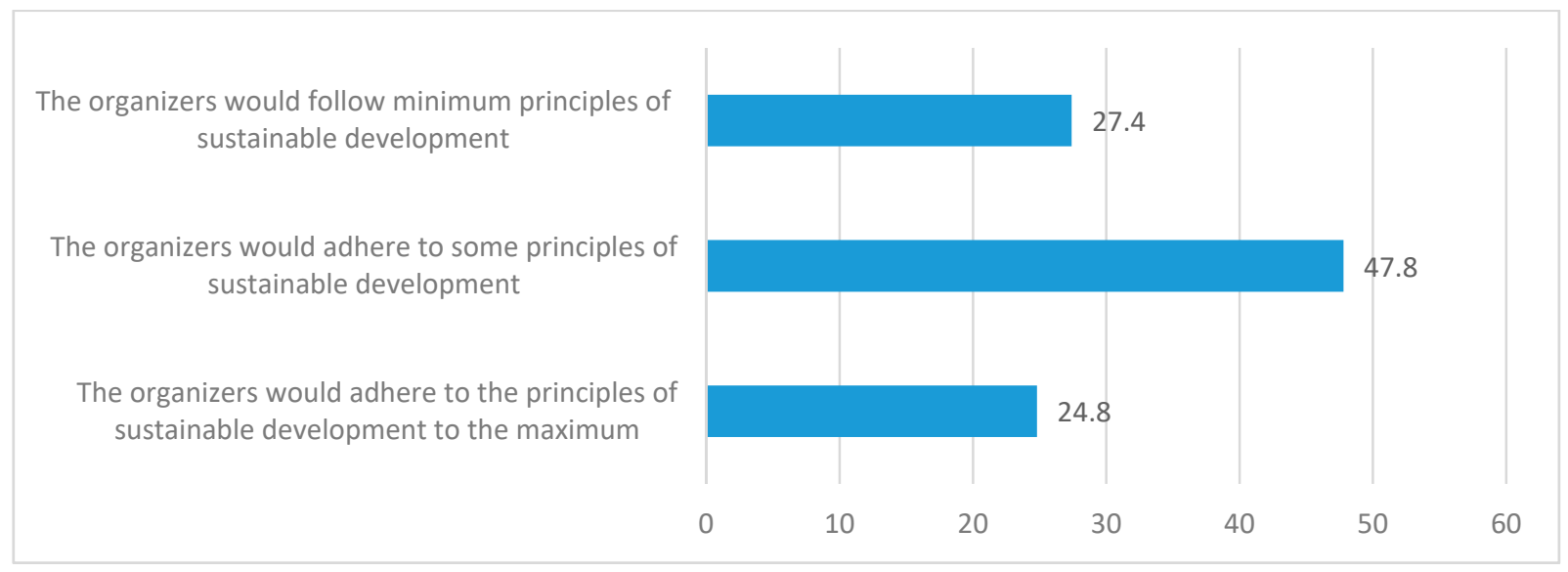

Figure 3. Assessment of sustainability criteria during the selection of music festivals. Source: compiled by the authors according to the empirical research data.

Most respondents think that it is important for them that the organisers of a music festival apply some of the principles of sustainable development. In fact, 24.8 percent believe that the organisers of music festivals should apply the principles of sustainable development to the maximum during the festival. A medium-strength correlation (correlation coefficient 0.513 ) was found, as well, among those who stated that they were constantly interested in the principles of sustainable development and those who said that the festival organisers should pay maximum attention to the principles of sustainable development during the festival.

In summary, it can be stated that the analysed music festival does not follow the principles of sustainable development yet. The respondents who took part in the survey express the same opinion. However, it is important to mention that many respondents believe that the principles of sustainable development need to be integrated into the music festivals. The principles of sustainable development must be observed during the mass events. Due to the pandemic situation, the music festival "Granatos Live" is moved to 2022. It is likely that, in 2022, the participants of the festival will be even more willing to express the principles of sustainable development during the festival. Based on the global experience, it is obvious that the Lithuanian music festival industry is not yet ready to integrate the principles of sustainable development into the music festivals. Meanwhile, music festival participants increasingly want these principles to be implemented.

\section{Discussion}

Thus, a discussion about the venue of the festival was performed with Interviewer X. With regards to the obtained research results, it was asked whether the issues of integration of principles of sustainable development into cultural events and music festivals are being considered at the municipal level. Interviewer $\mathrm{X}$ argued that such issues are discussed in a fragmented manner.

Often, the organisers of events and music festivals have not enough knowledge and competencies that would allow them to integrate the principles of sustainable development into the festival. "It simply came to our notice then. The same goes for research in this area." When it was asked how the situation could be improved, Interviewer X said that the emergence of indicators and monitoring systems for the integration of principles of sustainable development into the event industry as a whole should be initiated first at the "maybe municipal or maybe state" level.

It is important to organise trainings or competence-building courses on the integration of principles of sustainable development for the organisers of large-scale mass events. "After a similar discussion, Kaunas City Municipality started to use electricity from coffee grounds to light and illuminate the city's Christmas tree. Sustainable initiatives at the municipal level are always supported, but not so many." The interviewee was asked how the creative economy 
is analysed at the municipal level, whether the analysis is related to the principles of sustainable development. Interviewer $\mathrm{X}$ argued that the contribution of creative economy to the overall economy is unfortunately not calculated: " ... it is only based on approximate numbers when analysing the value created by a major event. Sometimes the calculation works, but not always ..."

We need to have in mind that "Granatos Live" is organized by private, not municipal organizers, so they are not obliged to provide us with statistics on attendance or benefits. According to Interviewer $X$, sustainable initiatives are nothing more than a part of the creative economy. However, this requires an extremely high level of interest from both organisers and participants, which is currently in a growth phase; thus, the results are not always noticeable.

Therefore, it can be said that the creative economy, perceived as the use of creativity and culture for economic development, manifests itself not only in the field of creative industries. However, the field of creative industries helps to bring more value to the added value of the creative economy. By linking the creative economy, creative industries, and sustainable development strategies, it is indeed useful to analyse individual sectors of the creative industries in order to gain a better understanding on how the creative economy works and whether or not the principles of sustainable development are reflected.

It is important that the creative economy is one of the fastest growing economies. What is important is that not only the net economic value is created, but intangible, emotional value as well. These values seem to intertwine in terms of culture as one of the essential components of the creative economy. Culture is transmitted, transformed, created, and restored. This is an important factor not only in terms of social development, but in terms of perception of sustainable development as well. Therefore, it is appropriate to develop scientific studies, practical activities linking the creative economy, creative industries and the pursuit of sustainable development, regarding the creative economy as an aspiration, expressed in the creative industries and able to integrate the principles of sustainable development as part of the culture. The analysis of the music festival industry shows that global examples, such as Coachella festivals, not only develop the creative economy within their industry, but are able to relate this to the principles of sustainable development as well. In the analysed case of the Lithuanian music festival, it can be seen that the festival creates economic value. Various creative economy tools are used to increase the economic value of the festival.

However, with regard to the principles of sustainable development, the organisers of the festival limit themselves to the implementation of principles that are regulated by law. This is shown by the rules of the analysed music festival. No voluntary principles of sustainable development apply without the rules. During the research, the organisers of the festival refused to give interviews and express their position on sustainable development issues. Therefore, it is difficult to judge how the festival will be organised in the future. The quantitative research data show that festival visitors want more sustainable development initiatives. Therefore, it can be hypothetically argued that regardless of such visitor preferences, the popularity of the festival, and hence its economic value, may decline.

\section{Conclusions}

The literature review of linkages between creative economy and sustainable development provided contradicting results and raised several important problems. The main problems could be grouped into the main categories. First, there is a contradiction between creative and sustainable economic development, since creative development means economic uncertainty, and sustainable development is oriented towards economic harmony. Secondly, people face different aspects of life beyond economy, including culture, ecology, ethics and education. Then, the question arises how to harmonise the different approaches? Thirdly, there is a contradiction between the ideology of progress with the idea of sustainable development. Even though harmony between creativity, economic activity, and 
sustainability is not obvious, the creative economy can provide a lot of benefits from a sustainability point of view; however, these benefits not always have been realised.

The case study of the biggest cultural event in Lithuania musical festival "Granatos Live" was presented, trying to analyse cultural economy and sustainability issues from a practical perspective.

After analysing the variables of perception of sustainable development principles and "Granatos Live" festival sustainability assessment by quantitative study, it has been found that there is a statistically significant relationship between them $(\mathrm{r}=0.505, p<0.001)$, and hypothesis H1: there is a positive correlation between the perception of sustainability principles and festival coherence, was confirmed.

The quantitative analysis of the disposable income and the requirements of the principles of sustainable development in music events showed that there was a weak statistically significant relationship between them $(\mathrm{r}=0.343, p<0.001)$. Thus, hypothesis $\mathrm{H} 2$ : there is a positive correlation between disposable income and the requirements of principles of sustainable development in music events, was approved.

A case study was chosen for the analysis of sustainability of the creative economy. The most important of all is to develop sustainability criteria that have to be assessed during a particular festival. The geographical location of the festival has to be assessed. The geographical location is linked to the museum area. The fire that once broke out during the festival made it clear that the creative economy could not always be linked to the sustainability criteria. A building lost in a fire cannot be calculated based on economic indicators alone.

The results of a quantitative study show that the festival participants are increasingly expressing the need for sustainable music festivals, but organisers are not taking necessary actions to address this need yet. It is likely that, in the near future, the festival organisers in Lithuania will have to start applying various sustainability criteria during the festival in order to attract more visitors and generate more income from such events as well to ensure environmental safety. There is a debatable question: will it be just a declarative and speculative application of sustainability criteria, or will there be a real move towards more sustainable music festivals in Lithuania.

The current case study demonstrates that customers or participants of creative economy events, such as music festivals, have clear preferences for events or cultural activities, having a positive impact on sustainable development. Therefore, for organising cultural events, the sustainability criteria should be very important for the organisers and other stakeholders in order to increase the attractiveness to customers engaged in the cultural activities.

The current study has several limitations. Just one cultural event was selected for the investigation of sustainability of cultural events as part of the creative industries. The future research is necessary for assessing the linkages between creative economy and sustainable development by analysing other segments of this sector. The current case study has a limited scope, as it was targeting participants of cultural events. More attention is necessary for the analysis of organisers' preferences in terms of sustainability of cultural events and their main drivers. The success factors and barriers need to be addressed in the future studies as well.

Author Contributions: Conceptualization; methodology; software; validation; formal analysis; investigation; resources; data curation; writing-original draft preparation; writing-review and editing; visualization; supervision; project administration; funding acquisition, T.K., D.S. and R.B. The authors equally contributed to the manuscript. All authors have read and agreed to the published version of the manuscript.

Funding: This research received no external funding.

Institutional Review Board Statement: The study was conducted according to the guidelines of the Declaration of Helsinki, and approved by the Institutional Review Board of Lithuanian Sports University (protocol code SMTEK-23 and date of approval 8 April 2020). 
Informed Consent Statement: Informed consent was obtained from all subjects involved in the study.

Data Availability Statement: Not applicable.

Conflicts of Interest: The authors declare no conflict of interest.

\section{References}

1. Jain, P.; Jain, P. Are the Sustainable Development Goals really sustainable? A policy perspective. Sustain. Dev. 2020, 28 , 1642-1651. [CrossRef]

2. Pradhan, P.; Costa, L.; Rybski, D.; Lucht, W.; Kropp, J. A Systematic Study of Sustainable Development Goal (SDG) Interactions. Earth's Futur. 2017, 5, 1169-1179. [CrossRef]

3. Streimikiene, D.; Mikalauskiene, A.; Kiausiene, I. The Impact of Value Created by Culture on Approaching the Sustainable Development Goals: Case of the Baltic States. Sustainability 2019, 11, 6437. [CrossRef]

4. Nocca, F. The Role of Cultural Heritage in Sustainable Development: Multidimensional Indicators as Decision-Making Tool. Sustainability 2017, 9, 1882. [CrossRef]

5. Brocchi, D. The Cultural Dimension of Sustainability. In Sustainability: A New Frontier for the Arts and Culture; Kagan, S., Kirchberg, V., Eds.; Verlag für Akademische Schriften: Frankfurt, Germany, 2008; pp. 26-58.

6. Štreimikienè, D.; Kačerauskas, T. The creative economy and sustainable development: The Baltic States. Sustain. Dev. 2020, 28, 1632. [CrossRef]

7. van Rompay, T.J.; Jol, T. Wild and free: Unpredictability and spaciousness as predictors of creative performance. J. Environ. Psychol. 2016, 48, 140-148. [CrossRef]

8. Leong, L.Y.C.; Fischer, R.; McClure, J. Are nature lovers more innovative? The relationship between connectedness with nature and cognitive styles. J. Environ. Psychol. 2014, 40, 57-63. [CrossRef]

9. Kačerauskas, T. Creative Society: Concepts and Problems. Cult.-Int. J. Philos. Cult. Axiolog. 2015, 12, 27-44. [CrossRef]

10. Howkins, J. The Creative Economy: How People Make Money from Ideas; Allen Lane: London, UK, 2001.

11. Kačerauskas, T. Discourses of ecology and the sketches of creative ecology in the context of sustainable development. Probl. Ekorozw.-Probl. Sustain. Dev. 2016, 11,31-39.

12. Galazova, S. Creative industries: Problems of market transformation. Terra Econ. 2016, 14, 31-41. [CrossRef]

13. Caves, R. Creative Industries: Contracts between Art and Commerce; Harvard University Press: Cambridge, UK, 2002.

14. Hart, S.L.; Milstein, M.B. Global sustainability and the creative destruction of industries. Sloan Manag. Rev. 1999, 41, 23-33.

15. Anderson, B. Imagined Communities: Reflections on the Origin and Spread of Nationalism, 2nd ed.; Verso: London, UK, 1991.

16. Naylor, T.D.; Florida, R. The Rise of the Creative Class: And How It's Transforming Work, Leisure, Community and Everyday Life. Can. Public Policy 2003, 29, 378. [CrossRef]

17. Tönnies, F.; Loomis, C.P. Community and Society; Michigan State University Press: East Lansing, MI, USA, 1957.

18. Throsby, D. Development Strategies for Pacific Island Economies: Is There a Role for the Cultural Industries? Asia Pac. Policy Stud. 2015, 2, 370-382. [CrossRef]

19. Andres, L.; Chapain, C. The Integration of Cultural and Creative Industries into Local and Regional Development Strategies in Birmingham and Marseille: Towards an Inclusive and Collaborative Governance? Reg. Stud. 2013, 47, 161-182. [CrossRef]

20. Stolarick, K.; Smirnova, O. Are creative and green cities also smart and sustainable? Smart cities as democratic ecologies. In Smart Cities as Democratic Ecologies; Araya, D., Ed.; Springer: Basel, Switzerland, 2015; pp. 87-115.

21. Kozina, J.; Istenič, S.P.; Komac, B. Green creative environments: Contribution to sustainable urban and regional development. Acta Geogr. Slov. 2019, 59, 119-126. [CrossRef]

22. Voytenko, Y.; McCormick, K.; Evans, J.; Schliwa, G. Urban living labs for sustainability and low carbon cities in Europe: Towards a research agenda. J. Clean. Prod. 2016, 123, 45-54. [CrossRef]

23. Ellul, J.; Wilkinson, J. The Technological Society; Vintage Books: New York, NY, USA, 1964.

24. Dewey, J. The Quest for Certainty: A Study of the Relation of Knowledge and Action. J. Philos. 1930, 27, 14. [CrossRef]

25. Böhm, S.; Misoczky, M.C.; Moog, S. Greening Capitalism? A Marxist Critique of Carbon Markets. Organ. Stud. 2012, 33, 1617-1638. [CrossRef]

26. Magdoff, F.; Foster, J.B. What Every Environmentalist Needs to Know About Capitalism. Mon. Rev. 2010, 61, 1. [CrossRef]

27. Cooke, P.; De Propris, L. A policy agenda for EU smart growth: The role of creative and cultural industries. Policy Stud. 2011, 32, 365-375. [CrossRef]

28. Werner, W.G. Responding to the undesired. state responsibility, risk management and precaution. Neth. Yearb. Int. Law 2005, 36, 57-82. [CrossRef]

29. Jonas, H. The Imperative of Responsibility: In Search of an Ethics in the Technological Age. J. Policy Anal. Manag. 1985, 4, 299. [CrossRef]

30. Giddens, A. Modernity and Self-Identity: Self and Society in the Late Modern Age; Polity Press and Blackwell Publishing: Cambridge, UK, 1991.

31. Beck, U.; Ritter, M. Risk society: Towards a new modernity. In Theory, Culture and Society; Sage: London, UK; Newbury Park, CA, USA; New Delhi, India, 1992. 
32. Bourdieu, P. Sur la Television. 2011. Available online: http://www.youtube.com/watch?v=vcc6AEpjdcY $\backslash \mathrm{T} 1 \backslash$ textgreater \{\} (accessed on 20 April 2021).

33. Cucuzzella, C. Creativity, sustainable design and risk management. J. Clean. Prod. 2016, 135, 1548-1558. [CrossRef]

34. Dursun, D. Global Creative Economy and Istanbul: A Focus on Film Industry Cluster. Int. Rev. Spat. Plan. Sustain. Dev. 2018, 6, 35-50. [CrossRef]

35. Howkins, J. Creative Ecologies: Where Thinking Is a Proper Job; New Brunswick and London Transaction Publishers: London, UK, 2009.

36. Kacerauskas, T. Creative Economy and the Idea of the Creative Society. Transform. Bus. Econ. 2020, 19, 43-52.

37. Kačerauskas, Kürybos Visuomenè [Creative society]; Technika: Vilnius, Lithuania, 2017.

38. United Nations General Assembly, 2019. International Year of Creative Economy for Sustainable Development. 2021. Available online: https://undocs.org/A/C.2/74/L.16/Rev.1 (accessed on 20 April 2021).

39. Bowdin, G.; Kennell, J.; Abson, E.; Wilde, N. Events Management, 2nd ed.; Routledge: Oxfordshire, UK, 2006.

40. The Show must go on. Environmental Impact Report and Vision for the UK Festival Industry. Powerful Thinking. 2015. Available online: http:/ / www.powerful-thinking.org.uk/site/wp-content/uploads/TheShowMustGoOnReport18.3.16.pdf (accessed on 20 April 2021).

41. United Nations Music and Environment Initiative. Available online: https://www.unep.org/music_env/about.asp (accessed on 20 April 2021).

42. Scalon, J. Singing to a Greener Tune. Current Status of the Music Industry in Addressing Environmental Sustainability. 2010. Available online: https: / / docplayer.net/8420054-Singing-to-a-greener-tune-current-status-of-the-music-industry-in-addressingenvironmental-sustainability.html (accessed on 20 April 2021).

43. Granatos Live. Available online: https://granatos.live/ (accessed on 20 April 2021).

44. The Open-Air Museum of Lithuania. Available online: http://www.llbm.lt/en/about-us/ (accessed on 20 April 2021).

45. Coachella. For Our Planet. Available online: https://coachella.com/sustainability (accessed on 20 April 2021).

46. Pakalniskiene, V. Tyrimo ir Ivertinimo Priemoniu Patikimumo ir Validumo Nustatymas. 2012. Available online: http: / / www.esparama.lt/documents /10157/490675/Pakalni\%C5\%A1kien\%C4\%97-Tyrimo-ir-\%C4\%AFvertinomo-patikimumas. pdf/e41bb87c-d17c-4796-900a-2f642882a548 (accessed on 20 April 2021). 